\title{
corporation and institutional members of the AMS
}

\author{
Sustaining Corporation Members \\ AccuWeather, Inc. \\ Alden Electronics, Inc. \\ Enterprise Electronics Corporation \\ GTE Federal Systems \\ Hughes Space \& Communications Company \\ ITT Aerospace/Communications Division \\ Space Systems/Loral \\ WSI Corporation
}

\section{Contributing Corporation Members}

University Corporation for Atmospheric Research,

National Center for Atmospheric Research

Unisys Weather Information Services

\section{Corporation and Institutional Members}

3SI

A.I.R., Inc.

The Abdus Salam International Centre for Theoretical Physics

ACT Sigmex B.V.

Advanced Forecasting Corporation

The Aerospace Corporation

Air Traffic Services, Civil Aeronautics Administration of the

Republic of China

Air Weather Service Technical Library

Andrew Canada Inc.

Argonne National Laboratory

ATIR, Inc.

Atmospheric and Environmental Research, Inc.

Automated Weather Source, Inc.

BBC Television, BBC Weather Centre

Baron Services, Inc.

Belfort Instrument Company

Brazilian Naval Commission, Instituto de Estudos do Mar

Almirante Paulo Moreira

Brock University Library

Bureau of Meteorology, National Meteorological Library

Campbell Scientific, Inc.

Caribbean Meteorological Institute

Centro Servizi Agrometeorologici per Il Friuli

Climatronics Corporation

Coastal Environmental Systems

Colorado State University, Libraries

Communications Electronics Inc.

Computer Sciences Corporation

Concurrent Computer Corporation

Control Data Corporation

Creighton University, Atmospheric Science Program

Dartmouth College Library

Davis Instruments Corp.

Deutscher Wetterdienst

Digilog Instruments

Dixon Weather Service

DOC/NOAA/NWS - Operational Support Facility

EDS Corporation

Edinburgh University Library
EKO Instruments Trading Co., Ltd.

Electronic Tele-Communications, Inc.

Empress Software, Inc.

Environment Canada, Mountain Weather Service Office

Environment Canada, Science Division

European Organisation for the Exploitation of

Meteorological Satellites (EUMETSAT)

Factory Mutual Engineering Corporation

Fernbank Science Center

Finnish Meteorological Institute

Florida Institute of Technology, Evans Library

Florida State University, Dept. of Meteorology

Foundation of River \& Basin Integrated Communications - FRICS

Frontier Research System for Global Change

GEOMET Technologies, Inc.

Global Atmospheric, Inc.

Global Hydrology and Climate Center

GTE Government Systems Corporation

Gill Instruments Limited

HANDAR, Inc.

Harris Corporation

Harvard University

Hawaii Pacific University, Meader Library/Periodicals

Hitachi Europe Ltd.

Hong Kong Observatory

ISRO Telemetry Tracking and Command Network, Doppler Weather Radar Project

Illinois State Water Survey

Indian Institute of Tropical Meteorology

Indiana University Library, Serials Department

Information Processing Systems of CA, Inc.

Innovative Emergency Management, Inc.

Institute of Global Environment and Society

Integrated Performance Decisions, Inc.

Irish Meteorological Service

Jenoptik Impulsphysik $\mathrm{GmbH}$

Jeppesen Dataplan, Incorporated

Kaijo Corporation, Gikan

Kavouras, Inc.

Kaysam Worldwide, Inc.

Kean College of New Jersey

Keesler AFB, 334 TRS/TTMV

Kipp \& Zonen

Korea Meteorological Administration

Laboratorie de Meteorologie Dynamique du CNRS

Lawrence Livermore National Laboratory

Litton PRC Inc.

Loral Data Systems

Lyndon State College

METEO FRANCE

Marta Systems, Inc.

Massachusetts Institute of Technology, Dept. of Meteorology

Massachusetts Institute of Technology, Lincoln Laboratory

MeteoMedia/The Weather Network

Meteorological Service of New Zealand Limited

Met One Instruments, Inc.

Millersville University of Pennsylvania, Dept. of Earth Sciences 


\section{corporation and institutional members of the AMS}

Mitretek Systems

The Mount Washington Observatory

Murray \& Trettel, Inc., Consulting Meteorologists

Niedersachsische Staats-u. Universitatsbibliothek

NIWA Wellington Library

NOAA AOML Library

NOAA Central Library

NOAA National Hurricane Center Library

NOAA Library Seattle

National Center for Environmental Prediction

National Climatic Data Center/NOAA, Department of Commerce/Library

National Institute for Space Research/Center for Weather Forecasts and Climate Studies

National Meteorological Library of the United Kingdom

National Severe Storms Laboratory

National Weather Service Training Center

North American Weather Consultants

Northern Video Graphics, Inc.

The Ohio State University, Dept. of Atmospheric Sciences

Oregon State University

PSC

Pacific Gas \& Electric Co.

Paroscientific, Inc.

Particle Measuring Systems, Inc.

Pell Marine Science Library, University of Rhode Island

Pennsylvania State University, Dept. of Meteorology

Pennsylvania State University, Pattee Library

Philippine Weather Bureau-PAGASA

Purdue University

Pyrometer Instrument Company, Inc.

Qualimetrics, Inc.

Radian Corporation

The Republic Group

Republic of Korea Air Force, 73rd Weather Group

Rosemount Aerospace Inc.

Rotronic Instrument Corporation

Royal Netherlands Meteorological Institute

SECOR International Incorporated

Saint Louis University, Dept. of Earth and Atmospheric Sciences

San Jose State University

Science Applications International Corporation, General Sciences Corporation

Scientific Technology, Inc. (ScTI)

Scintec

SeaSpace Corporation

Service Argos, Inc.

Sigmet, Inc.

Silicon Graphics/Cray Research

Snow Systems, Inc.

South Dakota School of Mines \& Technology

SpaceCom Systems, Inc.

Squitter Electronics, Inc.

Sterling Software

Strategic Weather Services

Surface Systems, Inc.

Sutron Corporation
Swedish Meteorological and Hydrological Institute, SMHI

Swiss Meteorological Institute

Systems Applications International, Inc.

Systems Management, Inc.

Technical Services Laboratory, Inc.

Texas A\&M University, Meteorology Department

Texas Electronics, Inc.

Texas Natural Resource Conservation Commission

The Titan Corporation

Unisys Weather Information Service

U.S. Department of Commerce, NOAA/ASMD ERL Lib.

U.S. Department of Commerce, NOAA/MASC Library, Periodicals

Universal Weather and Aviation

Universita di Bologna, Dipartimento di Fisica

Universitat Freiburg, Meteorologisches Institut

Universitat Innsbruck, Institut fur Meteorologie and Geophysik

University of Alabama in Huntsville

University of Arizona, Institute of Atmospheric Physics

University of Chicago, Dept. of the Geophysical Sciences

University of Copenhagen, Geophysical Institute

University of Guam, Water \& Energy Research Institute

University of Illinois, Dept. of Atmospheric Sciences

University of Melbourne, Earth Sciences Library

University of Michigan, Dept. of Atmospheric and Oceanic Science

University of Nevada, Desert Research Institute

University of New South Wales Library

University of North Carolina

University of Northern Colorado, Library

University of Oklahoma, Dept. of Meteorology

University of Rhode Island

University of Sheffield Library

University of Washington, Dept. of Atmospheric Sciences

University of Washington, Serials Services

University of Wisconsin-Madison, Space Science and Engineering Center

Uppsala University, Dept. of Meteorology

VCS Engineering GmbH

VIZ Manufacturing Co.

Valcom, Ltd.

Viking Instrument \& Photo

WTVT Television

Weather Bureau Pretoria, South Africa

Weather Central, Inc.

The Weather Channel

Weathernews, Inc.

Weather Services Corporation

The Weather Source, Inc.

Wels Research Corporation

Widespread Weather Services, Inc.

WNI Science \& Engineering

Woods Hole Oceanographic Institution

World Wildlife Fund, Climate and Energy Policy Division

Yale University, Dept. of Geology and Physics

Yankee Environmental Systems, Inc.

R. M. Young Company

Zentralanstalt fur Meteorologie und Geodynamik 